\title{
Risk assessment of antinutrient consumption of plant foods of south eastern Nigeria.
}

\author{
Ndie $\mathrm{EC}^{1^{*}}$, Okaka $\mathrm{JC}^{2}$ \\ ${ }^{1}$ Department of Nursing Science, Faculty of Health Sciences, Ebonyi State University, Abakaliki, Nigeria \\ ${ }^{2}$ Department of Food Science and Technology, Enugu State University of Science and Technology, Nigeria
}

\begin{abstract}
The risk assessment of anti-nutrient of consumed plant food of South Eastern Nigeria were estimated from actual quantity of plant food diet and the values compared with known risks levels from existing biological studies. The foods studied were yam, rice, garri, cassava fufu, tapioca and cowpea. Using the proportion of anti-nutrient composition of the plant food by weight, the anti-nutrients consumed were calculated from the weight of consumed food. The antinutrients were measures in $\mathrm{mg} / \mathrm{kg}$ of food. The results show that the levels of lectin $(0.05 \mathrm{mg} . \mathrm{kg})$, cyanide (0.21-5.78 mg/kg) acceptable by existing studies while levels of phytate (23.5-130.65 mg/ $\mathrm{kg})$, oxalate $(4.7-95.6 \mathrm{mg} / \mathrm{kg})$ and tannin $(108.3 \mathrm{mg} / \mathrm{kg})$ are high enough to be associated with health risk and further studies should be carried out to authenticate Maximum Residual Limits (MRL) of these ante nutrients in human to determine whether the levels on the foods consumed should be reduced or allow them as they are.
\end{abstract}

Keywords: Dietary intake, Plant Foods, Southern Eastern Nigeria.

Accepted on May 25, 2018

\section{Introduction}

Much work exists on the anti-nutrients content of Nigerian plant foods. Hardly is there a proximate analysis of individual plant foods in local and international Journals without information on the antinutrient value of these plant foods [1-4]. Very few attempts have been made to estimate the actual quality of these toxicants and anti-nutrients consumed from plant food in Nigerian diet and yet it is the actual quantity of these anti-nutrients consumed that really matter, in terms of disease causation. The common anti-nutrients of interest in South Eastern Nigeria diet are lectin, saponin, cyanide, phytate, tannin and oxalate. Though South Eastern Nigerian plant foods have a long history of use, yet most of the toxicological base indices are not available as required by the Codex Alimentrarius Commission. Their indices include the Acceptable Daily intake (ADI), the Maximum Residual Limit (MRLs) No Observed Adverse Effect level (NOAEL) and the Lowest Observed Adverse Effect level (LOAEL).

The management of risk arising from foods with anti-nutrients has been a major issue among the people and the government. Nutritional risks are reported in news media and Science Journals and such reports heighten public anxiety. The public demands disclosure of information on risk so that they can chose the appropriate direction to follow also want to participate in the regulatory decision making process itself $[5,6]$.

The risk identification involves the recognition that a well-defined hazard exists. This is followed by determining the magnitude of the hazard involved. These risks may then be evaluated in terms of their significance and acceptability, severity of the hazard involved as well as any associated benefits. Finally, suitable strategies for intervention may be developed in order to control or manage know risks to the extent feasible desirable [7,8]. This study is aimed at establishing the nutritional antinutrient intake and risks (if any) associated with antinutrient of plant food of South Eastern Nigerian diet.

\section{Materials and Methods}

A survey research design was used to estimate the amount of anti-nutrients consumed from plant foods of South Eastern Nigerian Diet. Diet intake of each antinutrient was determined from total food intake measured gravimetrically.

The food intake study was done using the method described by $[9,10]$. The oxalate content of the foods were determined by colorimetric methods (AOAC 1990), the Tannin content was determined using [11]. The phytic acid was determined using spectrophotometric method as described $[12,13]$. While lectin was determined using the method described [2]. The saponnin and cyanide content were determined as described [2,10].

The amount of anti-nutrients consumed from the plant foods were estimated from the food intake putting into consideration plant food combination diet. The results were compared to results of levels of various anti-nutrients which have been associated with pathology in animal and human studies.

\section{Statistical analysis}

The data collected were analysed statistically by means of Analysis of variance (ANOVA) and comparison of means of intake data by the method of Steel and Torrie using SPSS computer package [14].

\section{Results}

The total anti-nutrient consumption and risk evaluation of the anti-nutrient in plants food in South Eastern Nigeria are shown in Tables 1 and 2.

The results show that cassava products still provide the highest cyanide in the south-eastern state diet. Garri/ugu diet provides the highest level of cyanide $(5.78 \mathrm{mg} / \mathrm{kg})$. Tapioca/ beans provide the highest level of phytate $(130.65 \mathrm{mg} / \mathrm{kg})$ followed by garri/bean $(117.2 \mathrm{mg} / \mathrm{kg})$. A close observation 
Table 1. Total Anti-nutrient Consumption of South Eastern Nigerian Diets ( $\mathrm{mg} / \mathrm{kg}$ food).

\begin{tabular}{|c|c|c|c|c|c|c|}
\hline Food Combination & Cyanide & Phytate & Saponin & Tannin & Oxalate & Lectin \\
\hline Yam/rice & 1.39 & 35.8 & 0.33 & 1.35 & 10.76 & 0.062 \\
\hline Yam/green & 0.85 & 23.58 & 3.1 & 60.23 & 12.05 & 0.06 \\
\hline Amaranth & - & - & - & - & - & - \\
\hline Yam/ora & 0.78 & 25.65 & 0.67 & 82.03 & 59.05 & 0.06 \\
\hline Yam/ugu & 1.12 & 23.95 & 1.44 & 98.43 & 27.43 & 0.08 \\
\hline Yam/beans & 1.03 & 77.25 & 0.35 & 1.37 & 7.73 & 0.11 \\
\hline Rice/green & 0.34 & 46.88 & 2.83 & 0.06 & 4.39 & 0.052 \\
\hline Amaranth & - & - & - & - & - & - \\
\hline Garri/ogbono & 5.27 & 63.9 & 0.3 & 58.92 & 12.05 & 0.022 \\
\hline Garri/ora & 5.44 & 75.6 & 0.3 & 0.77 & 58.5 & 0.01 \\
\hline Garri/ugu & 5.78 & 63.9 & 1.17 & 80.76 & 66.9 & Nil \\
\hline Garri/bitter leave & 5.48 & 69.4 & 20.88 & 97.16 & 35.28 & 0.02 \\
\hline Garri/beans & 5.69 & 117.2 & 0.08 & 108.36 & 29.08 & Nil \\
\hline Cassava & 2.23 & 39.33 & 20.85 & 0.1 & 15.58 & 0.05 \\
\hline Fufu/bitter leave & - & - & - & - & - & - \\
\hline Cassava/fufu/ugu & 2.53 & 31.85 & 1.14 & 108.3 & 21.68 & Nil \\
\hline Cassava & 2.19 & 45.53 & 1.14 & 97.1 & 27.91 & 0.02 \\
\hline Fufu/ora & - & - & - & - & - & - \\
\hline Cassava & 0.22 & 33.83 & 0.3 & 0.71 & 59.53 & Nil \\
\hline Fufu/ogbono & - & - & - & - & - & - \\
\hline Tapioca/beans & 3.29 & 130.6 & 0.05 & 0.04 & 51.13 & 0.01 \\
\hline Beans/green & 0.7 & 88.33 & 2.85 & 58.94 & 9.48 & 0.07 \\
\hline Amaranth & - & - & - & - & - & - \\
\hline Bitter & 0.25 & 40.9 & 21.15 & 108.371 & 5.68 & 0.01 \\
\hline Leave/ogbono & - & - & - & - & - & - \\
\hline Ugu/ogbono & 0.55 & 35.4 & 1.44 & 97.81 & 63.98 & 0.03 \\
\hline Ora/ogbono & 0.21 & 47.1 & 0.67 & 81.41 & 95.6 & 0.01 \\
\hline
\end{tabular}

Table 2. Risk Assessment of Consumed Antinutrient from plant Food of South Eastern Diet.

\begin{tabular}{|c|c|c|c|}
\hline Anti-nutrient & Mean consumption & Stipulated residual limit mg/k of food & Study animal \\
\hline Lectin & 0.05 & $5 \mathrm{~A}$ & rat \\
\hline Phytate & $23.5-130.7 \mathrm{mg} / \mathrm{Kg}$ & $26.4-150 \mathrm{~B}$ & human \\
\hline Oxalate & $4.7-95.6 \mathrm{mg} / \mathrm{kg}$ & $50 \mathrm{C}$ & human \\
\hline Saponin & $0.03-0.2 \mathrm{mg} / \mathrm{kg}$ & $5-10 \mathrm{D}$ & rat \\
\hline Tannin & 108.37 & $120 \mathrm{E}$ & rat \\
\hline
\end{tabular}

of the result show that beans products provides the highest level of phytate in the South Eastern Nigeria diet. The results shows that bitter leave/ogbono provide the highest level of saponin $(21.15 \mathrm{mg} / \mathrm{kg})$. The highest level of tannin exposure come from Garri/bitter leave, cassava/fufu/bitter leave and bitter leave/ogbono combination $(108.3 \mathrm{mg} / \mathrm{kg})$, these are followed by yam/beans $(98.4 \mathrm{mg} / \mathrm{kg})$, while the least exposure was from tapioca/beans $(0.4 \mathrm{mg} / \mathrm{kg})$. The highest oxalate exposure comes from ora/ogbono $(66.9 \mathrm{mg} / \mathrm{kg})$ and the results show that lectin exposure is very low.

\section{Discussion}

\section{Risk assessment of consumed anti-nutrients}

Animal studies show that the adverse effect of high lectin oral consumption $(5 \mathrm{mg} / \mathrm{kg}$ ) affects absorption of protein and glucose [15]. The level found in this study is very low $(0.05 \mathrm{mg} / \mathrm{kg})$ and it is concluded that dietary lectin consumption do not pose any risk to south eastern Nigeria population. The low content may be due to the fact that lectin is heat labile.

Animal studies indicated that dietary phytate bind with zinc, iron and other deficiencies occur in population that subsists on unleavened whole grain bread containing $26.4-150 \mathrm{mg} /$ $\mathrm{kg}$ of phytate. The level of phytate found in Southern Eastern Nigeria diet is relatively high $(23.5-130.65 \mathrm{mg} / \mathrm{kg})$. It may be stated that dietary phytate in South Eastern Nigerian diet is a risk factor of micronutrient deficiency in the area. This needs further investigations.

Animal studies has shown that insoluble oxalates (calcium and Magnesium oxalates) are not absorbed and do not pose health risk unlike the soluble oxalates that reduce the bioavailability of calcium and help in the formation of kidney stones [16]. Nooman and Savage stated that diet with soluble oxalate of $50 \mathrm{mg} / \mathrm{kg}$ are excreted from urine and predispose the individual to kidney stones [17]. The results of his study indicated that the oxalate consumption from South Eastern Plant food is moderately high (4.7-95.6 $\mathrm{mg} / \mathrm{kg}$ ) and may constitute to some extent nutritional risk of calcium deficiencies and kidney stone formation.

It has been reported that oral intake of saponin of $5-10 \mathrm{mg} /$ $\mathrm{kg}$ produces local effect of corrosion and paralytic ileus [18]. From this study saponin content of south Eastern Nigeria diet is relatively low $(0.03-0.2 \mathrm{mg} / \mathrm{kg})$ and may not pose any health risk to the populace. 
Osagie reported that high level of dietary Tannin $(120 \mathrm{mg} / \mathrm{kg})$ reduces absorption of protein and damages the intestinal walls and Butler associated $200 \mathrm{mg} / \mathrm{kg}$ to damage to intestinal wall $[19,20]$. The result of this study show that tannin intake from South Eastern Nigerian Plant food is moderate high (108.37 $\mathrm{mg} / \mathrm{kg}$ ) and can affect the protein utilization in area with low protein intake.

Absorption of cyanide after ingestion with the food occurs across the mucosa membrane [21]. B-gluvosidase enzyme is activated in the alkaline environment of the gut to hydrolyse the cyanide glucoside to release hydrogen cyanide that is responsible for the toxic effect [22]. ACGIH reported that $80 \%$ of the absorbed cyanide is detoxified in the liver by the enzyme rhodanase and it is excreted from the urine [23-26]. According to Okofor the observed adverse effect level (OAEL) for cyanide in human diet is $9 \mathrm{mg} / \mathrm{kg}$ body weight. From this study the cyanide intake from the diet is relatively low $(21-5.78 \mathrm{mg} / \mathrm{kg})$. It is included from the study that cyanide consumption from south Eastern Nigerian met poses low health risk.

Though the level of phytate $(2.5-0.65 \mathrm{mg} / \mathrm{kg})$, oxalate $(47.95 .6$ $\mathrm{mg} / \mathrm{kg})$ and tannin $(108.37 \mathrm{mg} / \mathrm{kg})$ are high enough to be associated with health risk, yet their ability depend on their excretion and the frequency of consumption. There is a need to establish the excretion and consumption frequency of each to determine whether the levels in the food consumed should be reduced or left at it.

\section{Conclusion and Recommendation}

It was concluded from this study that the level of consumption of lectin cyanide and saponin are within the limit acceptable existing studies while that of phytate, malate and tannin are high enough to be associated with health risks going by visiting studies. It is recommended that further studies be carried out to authenticate maximum residual limits of these anti-nutrients in humans.

\section{References}

1. Liener IE. Implication of antinutrtional components of soybean foods. Critical Reviews in Foods Science and Nutrition. 1994;34(1):31-67.

2. Shi J, Arunasalam K, Yeung D, et al. Saponins from edible legumes; chemistry, processing and health benefits. J Med Food. 2004;7:67-78.

3. Singh U. Antinutritional factos of chicken and pigeonpea and their removal by processing. Plant Food for Human Nutrition. 1988;38:251-61.

4. Udoessien EI, Ifon ET. Chemical Evaluation of some Antinutrient Constituents of four species of yam in tropics. In (Osagie A. U. and Eka O. U. (Ed) Plant Food Post Harvest Research Unit, University of Benin, Benin City. 1990.

5. Munro IC, Krewski DR. Regulatory consideration in Risk Management In "carcinogens and mutagens in the environment Vol. II naturally occuracy compound (Hons and Stich) (Ed) CRC Press Inc, Boca Rota, Florida. 1983:156-65.
6. NAFDAC. What the Public need to know about thigs they eat, Abuja Nigeria. 2015.

7. Kate RW. Risk Assessment of Environment Hazards. John Wiley and Son. New York. 1978:12-3.

8. Whyte AV, Bolton I. Environmental Risk Assessment John Wiley and Sons New York 1980:10.

9. Ndie EC, Okaka JC. Dietary intake of Plant foods in South Eastern Nigeria Journal of Science and Technology. 2010;16.

10. Nweke FN, Okaka ANC, Ndie EC, Lead and Zinc Status of Staple Food Cultivars in Inyigba, Ebonyi State, Nigeria. 2008.

11. Deshpande SS, Cheryan M, Salunkhe DK. Tannin Analysis of Food Products. Crit Rev Food Sci Nutr. 1986;24(4):401-9.

12. Edeogu CO, Ekuma CE. Antinutrients level in steple food crops in Ebonyi State-Nigeria. Res J Environ Sci. 2007;1(6):302-9.

13. AOACH (1990) Official Method Analysis $12^{\text {th }}$ edition, Washington D.C: The Association.

14. Steel DG, Torrie JH. Procedures of Statistics. A Biometrical Approach $2^{\text {nd }}$ Ed New York, Mc Graw Hill Company Inc. 1980: 633.

15. Vijayakumari K, Siddhuraju P, Jonordhomon K. Effect of domestic processing on level of certain antinutrient in prospers chileness (Molina) Food Chemistry 1997;59: 361-371.

16. Williams AW, Wilson DM. Dietary intake, Absorption, metabolism and excretion of oxalate. Seminars in Nephrology 1990:10-8.

17. Nooman SC, Savage GP (2006) Oxalate content of Food: Food Science Lincon University.

18. Arshad M, Beg A, Shaikh AR. Buffer action of Saponin Analytical studies. Pakistan Journal of Science and Industrial Research 1965;899-1002.

19. Butcher LG. Effect of condensed tannin on animal nutrition. In 'Chemistry and significance of condensed tannin'. R.W. Hanninin way and J. J.Korchesy (Eds) Plenum Press New York 1989;391- 402.

20. Osagie AU, Antinutritional factors in Nutritional Quality of Plants Foods Osagie A. U. and Eke O. U. (Eds) Post harvest Research Unit University of Benin City1998:221-4.

21. Ellenhorn MJ, Barceloux DG. Medical Toxicology: Diagnosis and Treatment of Human Poisoning. Elsevier. 1988;234-63.

22. Padmaja G. Cyanide Detoxification in Cassava for Food and Feed use. Crit Rev Food Sci Nutr. 1995;35:259-39.

23. American Conference of Government Industrial Hygienists (ACGIH) (2001) Hydrogen Cyanide and Cyanide Salts. In Documentation of the Threshold Value and Biological Exposure Indices $8^{\text {th }}$ Ed, Cincinati OH 1-6. 
24. Jacobs. The chemical Analysis of Foods and Food products $3^{\text {rd }}$ Ed CBS Publishers and Distribution New Delhi. 1973.

25. http://www.fao.org/docrep/t0207e/T0207E00.htm

26. Pearson D. The chemical analysis of food Churchill Livingstone, London. 1976: 447-9.
*Correspondence to:

Elke N

Department of Nursing Science

Ebonyi State University

Nigeria

E-mail: chubike05@yahoo.com 